\title{
Physical-Chemical Composition, Fatty Acid Profile and Sensory Attributes of Meat of Lambs Fed With Saccharine Sorghum Silage
}

\author{
Luana Liz Medina Ledesma (Corresponding author) \\ Federal University of Grande Dourados, Faculty of Agrarian Sciences, Rodovia \\ Dourados/Itahum, Km 12 - Unidade II | Caixa Postal: 364, Dourados, Mato Grosso do Sul, \\ Brazil. E-mail: luanaliz2009@hotmail.com
}

Fernando Miranda de Vargas Junior

Federal University of Grande Dourados, Faculty of Agrarian Sciences, Rodovia Dourados/Itahum, Km 12 - Unidade II | Caixa Postal: 364, Dourados, Mato Grosso do Sul, Brazil. E-mail: fernandojunior@ufgd.edu.br

Jéssica de Oliveira Monteschio

Department of Animal Science, Federal University of Roraima, BR 174 - KM 12, Boa Vista, Roraima, Brazil. E-mail: jessicamonteschio@ hotmail.com

\section{Marciana Retore}

Embrapa Agropecuária Oeste, Rodovia BR 163, Zona Rural, Dourados-MS, Brazil. E-mail: marciana.retore@embrapa.br

\section{Tamires Marques Paes da Cunha}

Federal University of Grande Dourados, Rodovia Dourados/Itahum, Km 12 - Unidade II | Caixa Postal: 364, Dourados, Mato Grosso do Sul, Brazil. E-mail: Tamires.mpc@ gmail.com

\section{Ariádne Patrícia Leonardo}

Department of Animal Science, Federal University of Mato Grosso do Sul, R. UFMS, 222-824 - Vila Olinda, Campo Grande, Brazil. E-mail: aripatiileonardo@ hotmail.com 
Claudia Andréa Lima Cardoso

Natural Resources Studies Center, State University of Mato Grosso do Sul, Cidade Universitária de Dourados Rodovia Itahum, Km 12 s/n - Jardim Aeroporto, Dourados, Brazil.

E-mail: claudia@uems.com.br

\author{
Marco Antonio Previdelli Orrico Junior \\ Federal University of Grande Dourados, Faculty of Agrarian Sciences, Rodovia \\ Dourados/Itahum, Km 12 - Unidade II | Caixa Postal: 364, Dourados, Mato Grosso do Sul, \\ Brazil. E-mail: marcojunior@ufgd.edu.br
}

Received: Oct. 13, 2019 Accepted: Dec. 6, $2019 \quad$ Published: Feb. 5, 2020

doi:10.5296/jas.v8i2.16403

URL: https://doi.org/10.5296/jas.v8i2.16403

\begin{abstract}
The objective of this work was to evaluate the qualitative and sensory characteristics and the fatty acid profiles of the meat of lambs fed with silages of two saccharine sorghum varieties and compare them with forage sorghum and maize silages. Twenty non-castrated male Suffolk lambs were arranged in a completely randomised block design, and the treatments consisted of the following silages: forage sorghum (FORSOR), saccharine sorghum ('BRS506'), saccharine sorghum ('BRS511') and maize (MAIZE). The animals were slaughtered after 70 days in the feedlot. The carcasses were cooled at $4{ }^{\circ} \mathrm{C}$ for $24 \mathrm{~h}$. The longissimus thoracis et lumborum muscle was removed for analysis. No differences $(p>0.05)$ between treatments were found for chemical composition and qualitative and sensory characteristics of the evaluated meat. Lambs fed with 'BRS506' presented muscles with higher total unsaturated and monounsaturated fatty acids and with higher percentages of oleic acid. The BRS506 saccharin sorghum silage increased the meat total unsaturated and monounsaturated fatty acid contents, which are beneficial to human health; thus, this silage can replace maize silage in the feed for finishing lambs.
\end{abstract}

Keywords: BRS506, feedlot, meat quality, roughage

\title{
1. Introduction
}

Saccharine sorghum (Sorghum bicolor (L.) Moench) was improved to be used in ethanol production, mainly during the sugarcane off-season (De Nóbile \& Nunes, 2014), because it is a bioenergetic species whose culm is rich in fermentable sugars (Anandan, Zoltan, Khan, Ravi, \& Blümmel, 2012; Orrico Junior et al., 2015). In addition, this species resembles sugarcane plants due to a rapid productive cycle, mechanisable harvest, succulent culms and good bagasse production (Parrella, 2011), which can be used for bioenergy production and as animal feed (De Nóbile \& Nunes, 2014). 
Sorghum silage has been used for finishing animals in feedlots because it has high dry matter production and is less sensitive to short drought periods; thus, studies are needed for the development of hybrids more adapted, easily cultivated and ensiled (Neumann et al., 2002; Vaz et al., 2005).

The diet of lambs can modify their carcass conformation and meat physical-chemical and organoleptic properties, such as fatty acid profile, softness and colour (Franco, Crecente, Vázquez, Gómez, \& Lorenzo, 2013). The silage offered to animals can affect the quality of their final products, such as milk and meat (Campos et al., 2017; Milewski et al., 2014), denoting the importance of studies that investigate the diet effects (Holanda Júnior, 2006; Manarelli et al., 2019; Pereira et al., 2016). Considering that other studies (Manarelli et al., 2019; Orrico Junior et al., 2015) found variations in the effect of 'BRS506' saccharin sorghum silage on animal performance and carcass characteristics, it is important to evaluate the quality parameters of meat of sheep fed with this silage.

Thus, the objective of the present study was to evaluate the chemical, qualitative and sensory characteristics as well as the fatty acid profile of meat of lambs fed on silages of saccharine sorghum ('BRS506' and 'BRS511' varieties), forage sorghum and maize.

\section{Material and Methods}

\subsection{Location, Animals and Diet}

The analyses were performed in the Meat Quality and Carcass Evaluation, Management and Agricultural Waste laboratories of Federal University of Grande Dourados (UFGD) and the physicochemical analyses were performed in the laboratory of Embrapa Agropecuária Oeste. The experimental procedure was approved by the Committee of Ethics for the Use of Animals - CEUA (protocol no 33/2015) of the UFGD, Dourados, Mato Grosso do Sul (MS), Brazil.

Twenty male, uncastrated Suffolk lambs, with initial ages of $75 \pm 15$ days and initial weights of $21 \pm 7 \mathrm{~kg}$, were arranged in a completely randomised block design, fed different experimental diets ( 5 animals per treatment) and housed in individual stalls.

The isonitrogenous diets used were composed of roughage and concentrate in the proportion of 50:50. The concentrate was based on maize, soybean bran and minerals (Table 1). The diet was prepared for an average gain of $250 \mathrm{~g} \mathrm{day}^{-1}$, following the recommendations of the National Research Council (NRC, 2007). The experimental diets consisted of silages: forage sorghum (FORSOR), saccharine sorghum ('BRS506'), saccharine sorghum ('BRS511') and maize (MAIZE), which were produced at the Brazilian Agricultural Research Corporation-EMBRAPA (EMBRAPA Agropecuaria Oeste), Dourados, MS. 


\section{Macrothink}

Table 1. Ingredients and chemical composition of the diets supplied to lambs finished in feedlot

\begin{tabular}{lcccc}
\hline \multirow{2}{*}{ Ingredients (kg) } & \multicolumn{4}{c}{ Silage } \\
\cline { 2 - 5 } & FORSOR & BRS506 & BRS511 & MAIZE \\
\hline Roughage & 50.00 & 50.00 & 50.00 & 50.00 \\
Grain Maize & 32.30 & 32.30 & 32.30 & 34.80 \\
Soybean bran & 15.00 & 15.00 & 15.00 & 12.50 \\
Mineral premix & 1.00 & 1.00 & 1.00 & 1.00 \\
Lime & 1.00 & 1.00 & 1.00 & 1.00 \\
Urea & 0.47 & 0.47 & 0.47 & 0.47 \\
Ammonium Sulfate & 0.15 & 0.15 & 0.15 & 0.15 \\
Vitamin premix & 0.05 & 0.05 & 0.05 & 0.05 \\
Flowers of sulfur & 0.02 & 0.02 & 0.02 & 0.02 \\
15\% Lasalocid sodium & 0.01 & 0.01 & 0.01 & 0.01 \\
\hline Nutrients \% & \multicolumn{4}{c}{ Chemical composition (\%DS) } \\
\hline Dry matter & 33.90 & 35.06 & 36.45 & 34.60 \\
Mineral matter & 6.26 & 5.32 & 5.01 & 5.26 \\
Organic matter & 93.73 & 94.67 & 94.99 & 94.73 \\
Crude protein & 13.15 & 12.82 & 12.66 & 13.77 \\
Ether extract (EE) & 1.35 & 1.35 & 1.35 & 1.40 \\
Neutral detergent fiber (NDF) & 44.61 & 41.05 & 40.98 & 36.11 \\
Acidic detergent fiber (ADF) & 20.17 & 17.26 & 17.56 & 12.97 \\
Total digestible nutrients (TDN) & 70.32 & 69.09 & 70.25 & 74.66 \\
Total Calcium (g kg ${ }^{-1}$ diet) & 5.37 & 5.37 & 5.37 & 5.37 \\
Total phosphorus (g kg ${ }^{-1}$ diet) & 2.52 & 2.52 & 2.52 & 2.52 \\
\hline
\end{tabular}

FORSOR = Forage sorghum silage; BRS506 = saccharine sorghum silage; BRS511 = saccharine sorghum silage; MAIZE = Maize silage.

The average final weight of the animals was $33.75 \pm 1.34 \mathrm{~kg}$ at 70 days (experimental period in the feedlot); they were weighed under a $16 \mathrm{~h}$ period of fast of solids, and the slaughter was carried out in accordance with the legislation of the State Inspection Service in Brazil (Brasil, 2009). The carcasses were stored in a cold room at $4{ }^{\circ} \mathrm{C}$ for $24 \mathrm{~h}$. Subsequently, the longissimus thoracis et lumborum (LTL) muscle was removed from the carcasses and maintained at $-18{ }^{\circ} \mathrm{C}$ for further analysis.

\subsection{Instrumental Analysis of Meat}

The $\mathrm{pH}$ values $\left(\mathrm{pH}_{24}\right)$ were obtained using a $\mathrm{pH}$ meter with a 205/206 penetration probe, at $24 \mathrm{~h}$ after slaughter, according to Monteschio et al. (2018).

Meat colour determinations were performed as described by Monteschio et al. (2018), evaluating the brightness $\left(\mathrm{L}^{*}\right)$, the intensity of the red colour $(\mathrm{a} *)$ and the intensity of the yellow colour ( $\mathrm{b} *$ ) with a colorimeter (Minolta CR400 Chroma) after 30 minutes of sample exposure and the angle of exposure. Hue (HUE) and saturation index (Chroma) were 
determined by the following formula: Chroma $=(\mathrm{a} * 2+\mathrm{b} * 2)$ and hue angle $\left(\mathrm{h}^{\circ}\right)=(\arctan$ $(\mathrm{b} * / \mathrm{a} *))$. The water retention capacity (WRC) was evaluated according to the method described by Hamm (1961), wherein each meat sample was weighed before and after a force had been exerted on it, and the WRC was calculated by the amount of water lost. The result was expressed as percentage of retained water in relation to the initial sample weight.

Samples of $2.5 \mathrm{~cm}$ of the longissimus thoracis et lumborum muscle were baked in an electric oven that was preheated to $170{ }^{\circ} \mathrm{C}$, until the temperature of the geometric centre of the samples reached $70{ }^{\circ} \mathrm{C}$, which was monitored using a digital thermometer. The weight loss by cooking (WLC) was obtained by the difference between the raw sample weight and cooked sample weight; the values were used to calculate the total losses and were expressed as percentages (Monteschio et al., 2018).

These samples were cooled at room temperature and used to determine the shear force according to Hopkins, Toohey, Warner, Kerr, \& Van De Ven (2010), using a texture analyser (TA-XT2i) with a Warner-Bratzler blade in samples of $1.3 \mathrm{~cm}$ in diameter that were cut longitudinally to the fibres. The mean cut force of the cylinders was calculated to represent the shear force of the muscle and expressed in kgf.

\subsection{Fatty Acids}

The fatty acid profile was analysed on samples of the longissimus thoracis et lumborum muscles, which were lyophilised for $72 \mathrm{~h}$, and the total lipids were extracted with a chloroform/methanol mixture (section 2.10), according to Kempinski et al. (2017). The fatty acids compositions were determined by gas chromatography, using a gas chromatograph with an ionisation detector flame (Alves, Argandoña, Linzmeier, Cardoso, \& Macedo, 2016). For elution, a $100 \mathrm{~m} \times 0.25 \mathrm{~mm} \times 0.2 \mu \mathrm{m}$ fused silica capillary column was used. The methyl esters of fatty acids were identified by comparison of retention times of the sample compounds with the standards (Sigma) eluted under the same conditions as the samples.

\subsection{Centesimal Composition}

The centesimal composition of the meat was evaluated using samples of the longissimus thoracis et lumborum muscle, which were removed and packed in polyethylene packages, identified and stored at $-18{ }^{\circ} \mathrm{C}$, according to Moura et al. (2017), to determine their dry matter, crude protein, lipids and mineral matter contents, according to the methodologies of the AOAC (1990).

\subsection{Sensory Analysis}

The sensory analysis was carried out in accordance with the CEP ( $\mathrm{n}^{\circ}$ 334.478) CAAE (Certificate of Presentation for Ethical Assessment 14870613.0.0000.5160) by using $2.5 \mathrm{~cm}$ samples of the longissimus thoracis et lumborum muscle. These samples were baked in an electric oven that was preheated at $170{ }^{\circ} \mathrm{C}$, until the temperature of the geometric centre of the samples reached $70{ }^{\circ} \mathrm{C}$, which was monitored with a digital thermometer. Subsequently, the samples were packed in laminated paper, identified and served to a panel of untrained tasters who evaluated the following sensory attributes: flavour (flavour intensity associated 
with the ovine species), odour (intensity of smell associated with the sheep species), meat tenderness (texture felt as the meat was chewed) and global appreciation (evaluation of the samples adding all the parameters in general), using a non-structured hedonic scale of 10 points (0 to 10) (Devincenzi, Prunier, Meteau, \& Prache, 2019). Mineral water at room temperature and unsalted biscuits were served to the tasters between the sample tastings to remove the residual flavour of the meat. A total of 110 tasters with ages between 17 and 36 years (56.36\% women; $43.64 \%$ men) participated in the sensory analysis.

\subsection{Statistical Analysis}

The experiment was in a completely randomised block design, with four treatments and five replications. The attributes were evaluated by analysis of variance, using the MEANS and GLM (general linear model) procedures in the Minitab 17 program. Means and standard errors of the mean were calculated for each variable. The means were compared by the Tukey test $(p<0.05)$.

\section{Results}

The present data showed that there were no significant differences $(p>0.05)$ between the treatments for some of the lamb meat characteristics such as $\mathrm{pH}_{24}, \mathrm{WRC}$, WLC, shear force (SF) and colour of the meat (Table 2).

Table 2. Effect of different sorghum and maize silages on the meat characteristics of lambs finished in feedlots

\begin{tabular}{|c|c|c|c|c|c|c|}
\hline \multirow[b]{2}{*}{ Parameters } & \multicolumn{4}{|c|}{ Silage } & \multirow[t]{2}{*}{ MSE } & \multirow[t]{2}{*}{$P$-value } \\
\hline & FORSOR & BRS506 & BRS511 & MAIZE & & \\
\hline $\mathrm{pH}_{24}$ & 5.62 & 5.57 & 5.46 & 5.56 & 0.05 & 0.35 \\
\hline WRC (\%) & 49.24 & 51.76 & 48.87 & 46.28 & 1.77 & 0.24 \\
\hline WLC (\%) & 37.56 & 43.20 & 35.03 & 37.54 & 2.78 & 0.29 \\
\hline Shear Force (kgf) & 3.36 & 3.27 & 3.31 & 3.40 & 0.35 & 1.00 \\
\hline $\mathrm{L}^{*}$ & 36.49 & 35.27 & 36.49 & 36.33 & 0.78 & 0.67 \\
\hline$a^{*}$ & 16.25 & 17.33 & 16.61 & 16.71 & 0.34 & 0.29 \\
\hline$b^{*}$ & 6.69 & 7.56 & 7.10 & 7.60 & 0.35 & 0.30 \\
\hline HUE* & 22.36 & 25.20 & 23.06 & 23.53 & 1.28 & 0.52 \\
\hline Chroma* & 17.58 & 18.92 & 18.09 & 18.37 & 0.41 & 0.25 \\
\hline
\end{tabular}

FORSOR $=$ Forage sorghum silage $;$ BRS506 = saccharine sorghum silage; BRS511 = 
saccharine sorghum silage; MAIZE = Maize silage. MSE = Mean standard error; WRC = water retention capacity; WLC $=$ weight loss by cooking; $\mathrm{L}^{*}=$ luminosity; $\mathrm{a}^{*}=$ intensity of red color; $b^{*}=$ intensity of yellow color; $*$ HUE $=$ hue angle; $*$ Chroma $=$ saturation index.

The meat chemical composition of the evaluated lambs was not affected by the treatments; no significant differences $(p>0.05)$ were found for the chemical composition of the longissimus thoracis et lumborum (Table 3), with means of moisture, ash, protein and ether extracts of $76.19 \%, 1.45 \%, 14.09 \%$ and $3.23 \%$, respectively.

Table 3. Effect of different sorghum and maize silages on the chemical composition of the LTL muscle of lambs finished in feedlots

Silage

\begin{tabular}{lcccccc} 
Parameters & FORSOR & BRS506 & BRS511 & MAIZE & MSE & $P$-value \\
\hline Moist $(\%)$ & 76.22 & 76.21 & 75.72 & 76.62 & 0.69 & 0.78 \\
Ash $(\% \mathrm{NM})$ & 1.15 & 1.15 & 1.18 & 1.13 & 0.05 & 0.91 \\
Protein $(\% \mathrm{DM})$ & 13.78 & 14.12 & 14.32 & 14.17 & 0.53 & 0.89 \\
Ether extract $(\% \mathrm{NM})$ & 3.27 & 3.27 & 3.22 & 3.16 & 0.34 & 1.00 \\
\hline
\end{tabular}

FORSOR $=$ Forage sorghum silage; BRS506 = saccharine sorghum silage; BRS511 = saccharine sorghum silage; MAIZE = Maize silage. MSE = Mean standard error; NM = natural matter; $\mathrm{DM}=$ dry matter.

Table 4. Effect of different sorghum and maize silages on the sensory characteristics of the LTL muscle of lambs finished in feedlots

\begin{tabular}{lccccccr}
\hline & \multicolumn{7}{c}{ Silage } \\
\cline { 2 - 5 } Parameters & FORSOR & BRS506 & BRS511 & MAIZE & & MSE & $P$-value \\
\cline { 2 - 5 } Flavor & 6.54 & 6.42 & 7.06 & 6.58 & 0.22 & 0.25 \\
Odor & 6.40 & 6.57 & 6.72 & 6.69 & 0.24 & 0.79 \\
Tenderness & 7.93 & 7.47 & 7.59 & 7.50 & 0.20 & 0.32 \\
Overall appreciation & 7.08 & 6.61 & 7.23 & 7.15 & 0.19 & 0.10 \\
\hline
\end{tabular}

FORSOR = Forage sorghum silage; BRS506 = saccharine sorghum silage; BRS511 = saccharine sorghum silage; MAIZE = Maize silage . MSE = Mean standard error. 
The results of the sensory analysis parameters of the LTL muscle showed no difference between treatments $(p>0.05)$ (Table 4), with means for flavour, odour, tenderness and overall appreciation of 7.01, 6.65, 5.97, 6.59, 7.62 and 7.01, respectively.

The treatments presented differences $(p<0.05)$ in the classification of saturated fatty acids for the caproic (C10:0), myristic (C14:0), pentadecanoic (C15:0), palmitic (C16:0), heptadecanoic (C 17:0), stearic (C 18:0) and total saturated fatty acids (Table 5). The lowest levels of $\mathrm{C} 14: 0$ and $\mathrm{C} 17: 0$ fatty acids $(2.55 \%$ and $1.41 \%$, respectively) were found in the meat of animals fed with 'BRS511' saccharine sorghum silage, and the lowest levels of C16:0 and C18:0 saturated fatty acids and total saturated fatty acids were found in animals fed with 'BRS506' saccharine sorghum silage (Table 5).

Table 5. Effect of different sorghum and maize silages on the saturated fatty acid composition in the LTL muscle of lambs finished in feedlots

\begin{tabular}{|c|c|c|c|c|c|c|}
\hline \multirow[b]{2}{*}{ Parameters } & \multicolumn{4}{|c|}{ Treatments } & \multirow[b]{2}{*}{ MSE } & \multirow[b]{2}{*}{$P$-value } \\
\hline & FORSOR & BRS506 & BRS511 & MAIZE & & \\
\hline Capric C10:0 & $0.10^{\mathrm{b}}$ & $0.10^{\mathrm{ab}}$ & $0.11 \mathrm{a}$ & $0.11^{\mathrm{a}}$ & 0.00 & 0.01 \\
\hline Lauric C12:0 & $0.12^{\mathrm{a}}$ & $0.12^{\mathrm{a}}$ & $0.12^{\mathrm{a}}$ & $0.12^{\mathrm{a}}$ & 0.00 & 0.34 \\
\hline Myristic C14:0 & $2.83^{\mathrm{a}}$ & $2.74^{\mathrm{a}}$ & $2.55^{\mathrm{b}}$ & $2.78^{\mathrm{a}}$ & 0.02 & $<0.001$ \\
\hline Pentadecanoic C15:0 & $0.23^{\mathrm{a}}$ & $0.21^{b c}$ & $0.22^{\mathrm{ab}}$ & $0.19^{c}$ & 0.01 & $<0.001$ \\
\hline Palmitic C16:0 & $24.01^{\mathrm{a}}$ & $23.09^{b}$ & $23.85^{\mathrm{a}}$ & $24.05^{\mathrm{a}}$ & 0.05 & $<0.001$ \\
\hline Heptadecanoic C17:0 & $1.52^{\mathrm{a}}$ & $1.46^{\mathrm{bc}}$ & $1.41^{\mathrm{c}}$ & $1.52^{\mathrm{ab}}$ & 0.01 & $<0.001$ \\
\hline Stearic C18:0 & $18.20^{\mathrm{b}}$ & $18.37^{\mathrm{b}}$ & $18.97^{\mathrm{a}}$ & $18.27^{b}$ & 0.11 & $<0.001$ \\
\hline Arachidonic C20:0 & $0.11^{\mathrm{a}}$ & $0.11^{\mathrm{a}}$ & $0.11^{\mathrm{a}}$ & $0.11^{\mathrm{a}}$ & 0.00 & 0.72 \\
\hline Total saturated & $47.14^{\mathrm{a}}$ & $46.22^{\mathrm{b}}$ & $47.31^{\mathrm{a}}$ & $47.17^{\mathrm{a}}$ & 0.14 & $<0.001$ \\
\hline
\end{tabular}

FORSOR $=$ Forage sorghum silage; BRS506 = saccharine sorghum silage; BRS511 = saccharine sorghum silage; MAIZE = Maize silage. MSE $=$ Mean standard error. Means followed by the same letter in the row do not differ at $5 \%$ probability. 
Table 6. Effect of different sorghum and maize silages on the monounsaturated and polyunsaturated fatty acid compositions in the LTL muscle of lambs finished in feedlots

Treatments

Parameters

FORSOR BRS506 BRS511 MAIZE MSE $P$-value

Myristoleic C14:1

$0.10^{\mathrm{a}}$

$0.11^{\mathrm{a}}$

$0.11^{\mathrm{a}}$

$0.11^{\mathrm{a}}$

0.70

Palmitoleic C16:1

$1.62^{\mathrm{a}}$

$1.57^{\mathrm{b}}$

$1.59^{\mathrm{ab}}$

$1.58^{\mathrm{b}} \quad 0.01$

0.01

Oleic C18:1

$44.21^{\mathrm{b}}$

$44.91^{\mathrm{a}}$

$43.91^{\mathrm{b}}$

$43.84^{\mathrm{b}}$

$0.15<0.001$

Linoleic C18:2 $\omega 6$

$3.44^{\mathrm{b}}$

$3.55^{\mathrm{a}}$

$3.59^{\mathrm{a}}$

$3.56^{\mathrm{a}}$

$0.02<0.001$

Linolenic C18:3 $\omega 3$

$0.18^{\mathrm{ab}}$

$0.18^{\mathrm{ab}}$

$0.16^{\mathrm{b}}$

$0.18^{\mathrm{a}}$

0.00

0.03

Eicosenoic C20:1

$0.10^{\mathrm{a}}$

$0.10^{\mathrm{a}}$

$0.10^{\mathrm{a}}$

$0.10^{\mathrm{a}} \quad 0.00$

0.47

Eicosadienoic C20:2

$0.10^{\mathrm{a}}$

$0.10^{\mathrm{a}}$

$0.11^{\mathrm{a}}$

$0.10^{\mathrm{a}} \quad 0.00$

0.70

Eicosatrienoic a C20:3 $\omega 6$

$0.10^{\mathrm{a}}$

$0.10^{\mathrm{a}}$

$0.10^{\mathrm{a}}$

$0.10^{\mathrm{a}} \quad 0.00$

0.91

Eicosatrienoic b C20:3 $\omega$

$1.40^{\mathrm{b}}$

$1.50^{\mathrm{ab}}$

$1.50^{\mathrm{ab}}$

$1.61^{\mathrm{a}}$

$0.02<0.001$

Arachidonic C20:4
$0.19^{\mathrm{a}}$

$0.19^{\mathrm{a}}$

$0.19^{\mathrm{a}}$

$0.19^{\mathrm{a}}$

0.00

0.68

Eicosapentaenoic C20:5

$0.10^{\mathrm{a}}$

$0.10^{\mathrm{a}}$

$0.10^{\mathrm{a}}$

$0.11^{\mathrm{a}}$

0.00

0.46

n-6

$3.51^{\mathrm{b}}$

$3.65^{\mathrm{a}}$

$3.73^{\mathrm{a}}$

$3.66^{\mathrm{a}}$

$0.02<0.001$

n-3

$1.68^{\mathrm{b}}$

$1.76^{\mathrm{ab}}$

$1.76^{\mathrm{ab}}$

$1.86^{\mathrm{a}}$

$0.03<0.001$

Total unsaturated

$52.86^{\mathrm{b}}$

$53.80^{\mathrm{a}}$

$52.67^{\mathrm{b}}$

$52.85^{\mathrm{b}}$

$0.14<0.001$

Total monounsaturated

$46.96^{\mathrm{b}}$

$47.66^{\mathrm{a}}$

$46.40^{\mathrm{b}}$

$46.55^{\mathrm{b}}$

$0.14<0.001$

Total polyunsaturated

$5.91^{\mathrm{b}}$

$6.14^{\mathrm{a}}$

$6.27^{\mathrm{a}}$

$6.30^{\mathrm{a}}$

$0.04<0.001$

FORSOR = Forage sorghum silage; BRS506 = saccharine sorghum silage; BRS511 = saccharine sorghum silage; MAIZE = Maize silage. MSE = Mean standard error. Means followed by the same letter in the row do not differ at $5 \%$ probability. 
Differences were found for total monounsaturated and unsaturated fatty acid contents $(p<$ 0.05). Oleic fatty acid (C18:1) represented $44.91 \%$ of the total unsaturated fatty acid composition (Table 6). Higher levels of C18:1, total unsaturated and total monounsaturated fatty acids were found in the meat of animals treated with 'BRS506', and lower levels of C18: $2 \omega 6$ linoleic, n-6 and total polyunsaturated fatty acids were found in the treatment with forage sorghum (Table 6). No differences were found between treatments $(p>0.05)$ for the nutritional and functional classifications and enzymatic activities in the lambs' meat (Tables 7 and 8).

Table 7. Effect of different sorghum and maize silages on the nutritional classification of fatty acids as of function of their relations in the LTL muscle of lambs finished in feedlots

\begin{tabular}{lccccccc}
\hline & \multicolumn{9}{c}{ Silage } & & \\
\cline { 2 - 5 } Parameters & FORSOR & BRS506 & BRS511 & MAIZE & MSE & $P$-value \\
\cline { 2 - 5 } Omega 6:3 & 2.03 & 2.11 & 2.07 & 2.04 & 0.03 & 0.43 \\
Unsaturated:Saturated & 1.13 & 1.12 & 1.12 & 1.15 & 0.01 & 0.17 \\
Monounsaturated:Saturated & 1.00 & 0.99 & 0.99 & 1.02 & 0.01 & 0.13 \\
Polyunsaturated:Saturated & 0.13 & 0.13 & 0.13 & 0.13 & 0.00 & 0.80 \\
\hline
\end{tabular}

FORSOR = Forage sorghum silage; BRS506 = saccharine sorghum silage; BRS511 = saccharine sorghum silage; MAIZE = Maize silage. MSE = Mean standard error. 
Table 8. Effect of different sorghum and maize silages on the functional fatty acid composition and enzyme activity in the LTL muscle of lambs finished in feedlots

\begin{tabular}{|c|c|c|c|c|c|c|}
\hline \multirow[b]{2}{*}{ Parameters } & \multicolumn{4}{|c|}{ Silage } & \multirow[b]{2}{*}{ MSE } & \multirow[b]{2}{*}{$P$-value } \\
\hline & FORSOR & BRS506 & BRS511 & MAIZE & & \\
\hline Hypercholesterolemics ${ }^{1}$ & 28.31 & 28.43 & 28.41 & 28.02 & 0.20 & 0.49 \\
\hline Hypocholesterolemics ${ }^{2}$ & 48.83 & 48.58 & 48.53 & 49.12 & 0.22 & 0.29 \\
\hline Neutrals $^{3}$ & 18.40 & 18.53 & 18.81 & 18.48 & 0.18 & 0.47 \\
\hline Residuals $^{4}$ & 1.80 & 1.81 & 1.79 & 1.79 & 0.03 & 0.94 \\
\hline Thrombogenicity ${ }^{5}$ & 0.68 & 0.69 & 0.69 & 0.68 & 0.01 & 0.68 \\
\hline Atherogenicity ${ }^{6}$ & 0.35 & 0.35 & 0.35 & 0.35 & 0.00 & 0.97 \\
\hline$\Delta 9$-desaturase C:16 & 6.26 & 6.27 & 6.28 & 6.29 & 0.05 & 0.98 \\
\hline$\Delta 9$-desaturase C:18 & 70.77 & 70.52 & 70.13 & 70.82 & 0.27 & 0.32 \\
\hline Elongase & 71.15 & 71.04 & 71.07 & 71.57 & 0.20 & 0.30 \\
\hline
\end{tabular}

FORSOR $=$ Forage sorghum silage , BRS506 = saccharine sorghum silage; BRS511 = saccharine sorghum silage; MAIZE = Maize silage. MSE = Mean standard error. ${ }^{1}(\mathrm{C} 12: 0+$ $\mathrm{C} 14: 0+\mathrm{C} 16: 0) ;{ }^{2}(\mathrm{C} 18: 1+\mathrm{C} 18: 1$ cis $9+\mathrm{C} 18: 2$ cis-9,12 + C18:3 cis-9, 12, $15+\omega 6+\omega 3)$; ${ }^{3}(\mathrm{C} 14: 1+\mathrm{C} 16: 1+\mathrm{C} 18: 0+\mathrm{C} 10: 0) ;{ }^{4}$ (AG branched C15:0; C17:0 C18:1 cis C18:2 isomers); ${ }^{5}((\mathrm{C} 14: 0+\mathrm{C} 16: 0+\mathrm{C} 18: 0) /[(0,5 \times \Sigma \mathrm{AGMI})+(0,5 \times \Sigma \omega 6)+(3 \times \Sigma \omega 3)+(\Sigma \omega 3 / \Sigma \omega 6)]) ;$ ${ }^{6}([(\mathrm{C} 12: 0+(4 \times \mathrm{C} 14: 0)+\mathrm{C} 16: 0] /(\Sigma \mathrm{AGM}-\mathrm{I}+\Sigma \omega 6+\Sigma \omega 3))$.

\section{Discussion}

\subsection{Qualitative Characteristics}

The mean $\mathrm{pH}$ of the meat samples at $24 \mathrm{~h}$ after slaughter was within the normal range (5.5 and 5.6) (Page, Wulf, \& Schwotzer, 2001). It should be emphasised that normal pH values suggest that other indicative parameters of meat quality, such as colour and texture, will have good results (Bonagurio, Pérez, Garcia, Bressan, \& Lemos, 2003).

Meat colour is the most acceptable parameter of meat freshness and quality by consumers and is an important sensory aspect of meat (Bressan, Prado, Pérez, Lemos, \& Bonagurio, 2001). The results of meat colour found in the present study are consistent with those reported by Bressan et al. (2001), who found $\mathrm{L}^{*}$ of $30.0-49.5$, $\mathrm{a}^{*}$ of $8.2-23.5$ and $\mathrm{b}^{*}$ of $3.4-11.1$. 
According to Khliji, Van De Ven, Lamb, Lanza, \& Hopkins (2010), the acceptable limit for $\mathrm{L}^{*}$ in lamb meat is 34 to 35 , which is similar to the values found in the present study (35.89) and lower than that (39.16) reported by Campos et al. (2017) in meat of lambs fed with different silages.

The mean values of lamb meat tenderness found in the present study (3.33 kgf) are classified as soft (Tatum, Smith, \& Belk, 2000). Similar result was reported by Lara, Bragiato, Rabelo, Messana, \& Reis (2018), who found mean of $3.00 \mathrm{kgf}$ when evaluating the meat quality of lambs fed with maize silage.

Meat tenderness is the result of several factors, such as species, breed, age, meat fat, and muscle fibres post-mortem of the animal (Saccà, Corazzin, Bovolenta, \& Piasentier, 2019). It is an important factor in meat quality and affects its acceptability by the consumer (Arguello, Castrol, Sanchez-Maciasi, \& Capote, 2012).

\subsection{Centesimal Analysis}

The results were similar to others reported in the literature. According to Madruga, Sousa, Rosales, Cunha, \& Ramos (2005), sheep meat chemical composition consists, on average, of $75 \%$ moisture, $19 \%$ protein, $4 \%$ fat and $1 \%$ mineral matter, with possible variations in these levels depending on the age, genotype, sex, castration, pre and post-slaughter management and diet of the animal (Tshabalala, Strydom, Webb, \& De Kock, 2003).

He, Wu, Wang, Meng, \& Zhou (2018), Campos et al. (2017) and Lara et al. (2018) found no differences in the chemical composition of lamb meat receiving different silages in their diets. These are similar results to those found in the present study, in which only the fat content was higher $(3.23 \%)$ than those found by those previous authors. According to Bezerra et al. (2016), this value characterises the meat as lean because of a fat content of less than $5 \%$.

\subsection{Sensory Analysis}

There were no differences between the means attributed to the sensory characteristics of the evaluated lamb meat. The palatability of the meat is generally described in terms of tenderness, juiciness and flavour notes (Thompson et al., 2005). Madruga et al. (2005) evaluated different silages and hays and found differences between treatments, with higher values for sheep odour (4.87) and lipid content (8.38) in the meat of animals treated with maize silage. These results were lower than that found in the present study for sheep odour (6.69) and higher than that found for ethereal extract (3.16\%) in the meat of animals fed with maize silage. This confirms the importance of lipids in the formation of the meat odour characteristics (Madruga et al., 2002; Mottram, 1998). The characteristics odour and flavour of meat are directly related to the fat content present in the muscles (Madruga, 1997).

\subsection{Fatty Acid Composition}

The fatty acids found in the highest concentrations were palmitic $(23.75 \%)$, stearic $(18.45 \%)$ and myristic $(2.72 \%)$ saturated fatty acids, oleic monounsaturated (44.21\%) and linoleic polyunsaturated (53\%), constituting $92.66 \%$ of the total fatty acids of the evaluated lamb meat. High concentrations of these fatty acids in the lamb meat was also found by Leão et al. 
(2011) when evaluating the effect of maize silage on the meat fatty acid composition.

Myristic (C14:0) and palmitic (C16:0) saturated fatty acids are hypercholesterolemic, but the stearic acid (C18:0), which represents 10 to $20 \%$ of the fat produced by ruminants, does not have this property (Leão et al., 2011). According to Novello, Franceschini, \& Quintiliano (2008), unlike other saturated fatty acids, C18:0 is classified as non-atherogenic (neutral), showing that the increase of this fatty acid in the meat of animals fed with 'BRS511' silage is not harmful for human consumption; the meat of the animals of this treatment had low C14:0 and C16:0 and high C18:0 contents.

Mono and polyunsaturated fatty acids are beneficial to human health (Perini et al., 2010). According to Cooper et al. (2004), the diet may alter the percentage of palmitoleic (C16:1 107$)$ and oleic $(\mathrm{C} 18: 1 \omega 9)$ acids in the meat. The highest percentages $(p<0.05)$ of oleic acid were found in the meat of lambs finished with the 'BRS506 silage'. The highest percentages $(p<$ 0.05) of palmitoleic acid were found in animals treated with forage sorghum, which did not differ from the meat of animals treated with 'BRS511' silage.

Not all saturated fatty acids are hypercholesterolemic (which increase LDL cholesterol); the most undesirable fatty acid would be the myristic $(\mathrm{C} 14: 0)$, which presented the lowest mean $(2.55 \%)$ in the meat of animals fed with 'BRS511 silage'. The palmitic acid (C16:0) had a mean of $23.75 \%$ of the total fatty acids; according to Fernandes et al. (2010) and French, O'riordan, Monahan, Caffrey, \& Moloney (2003), it has the lowest hypercholesterolemic effect. Stearic acid (C18:0) was an average of $18.45 \%$ of the total fatty acids; its effect is null, since it is converted to oleic acid (C18:1) in the organism (Sinclair, 1993) without affecting the blood cholesterol levels. The treatment with 'BRS511' resulted in the lowest percentage of total saturated fatty acids in the lamb meat (46.22\%).

On average, the amounts of unsaturated (53.04\%), monounsaturated (46.89\%) and polyunsaturated $(6.15 \%)$ fatty acids indicate that lamb meat is rich in "good" fat, confirming the results found by Monteiro, Fernandes, \& Barros (2007) and Leão et al. (2011).

The polyunsaturated/saturated ratio (PUFA:SFA) of the lamb meat (0.13) (Table 7) was below the ideal level (0.40) to be considered a healthy food, as recommended by the Department of Health of the United Kingdom to avoid diseases associated with the consumption of saturated fats (Wood et al., 2004). According to Scollan et al. (2001) and Scollan et al. (2006), the PUFA:SFA ratio in meat is generally low (0.1) and varies between 0.06 and 0.15; the nutritional management does not increase the PUFA:SFA ratio above the normal level because of the high biohydrogenation degree of polyunsaturated compounds in the rumen. Fernandes et al. (2010) and Leão et al. (2011) did not find significant effects on the PUFA:SFA ratio in animals fed with maize silage or sugarcane silage.

Thrombogenicity indexes, with a mean of 0.68 , were within the range recommended by Ulbricht \& Southgate (1991), who indicate a maximum amount of 1.27. The atherogenicity index was also lower (0.35) than those recommended for human health (0.72). Ulbricht \& Southgate (1991) proposed these indexes for comparison of diets and foods that participate in possible causes of coronary diseases, mainly related to saturated fatty acids. 


\section{Conclusions}

Saccharin sorghum silages do not alter the chemical, qualitative and sensory characteristics of lamb meat, which indicates that these silages can be used for feeding finishing lambs and can replace maize silage.

The 'BRS506' saccharin sorghum silage also increases total unsaturated and monounsaturated fatty acids in the lamb meat, which are beneficial to human health.

\section{References}

Alves, A. V., Argandoña, E. J. S., Linzmeier, A. M., Cardoso, C. A. L., \& Macedo, M. L. R. (2016). Chemical composition and food potential of pachymerus nucleorum larvae parasitizing acrocomia aculeata kernels. PloS one, 11(3). https://doi.org/10.1371/journal.pone.0152125

Anandan, S., Zoltan, H., Khan, A., Ravi, D., \& Blümmel, M. (2012). Feeding value of sweet sorghum bagasse and leaf residues after juice extraction for bio-ethanol production fed to sheep as complete rations in diverse physical forms. Animal feed science and technology, 175(3-4), 131-136. https://doi.org/10.1016/j.anifeedsci.2012.05.005

AOAC. (1990). Official Methods of Analysis: Changes in Official Methods of Analysis Made at the Annual Meeting. Supplement (Vol. 15): Association of Official Analytical Chemists.

Arguello, A., Castrol, N., Sanchez-Maciasi, D., \& Capote, J. (2012). Effect of Early Nutrition on Carcass and Meat Quality of Young Goats Under Milk Production Systems. Goat Meat Production and Quality, 324-350.

Bezerra, L., Barbosa, A., Carvalho, G., Simionato, J., Freitas Jr, J., Araújo, M., ... Carvalho, B. (2016). Meat quality of lambs fed diets with peanut cake. Meat science, 121, 88-95. https://doi.org/10.1016/j.meatsci.2016.05.019

Bonagurio, S., Pérez, J. R. O., Garcia, I. F. F., Bressan, M. C., \& Lemos, A. L. S. C. (2003). Quality of Meat Production of Purebred Santa Inês and Crossbred Texel x Santa Inês Lambs at Different Slaughter Weights. Revista Brasileira de Zootecnia, 1981-1991.

Brasil. (2009). Manual de Legislação: programas nacionais de saúde animal do Brasil: Departamento de Saúde Animal e Secretária de Defesa Agropecuária.

Bressan, M. C., Prado, O. V., Pérez, J. R. O., Lemos, A., \& Bonagurio, S. (2001). Efeito do peso ao abate de cordeiros Santa Inês e Bergamácia sobre as características físico-químicas da carne. Ciência e Tecnologia de Alimentos, 21(3), 293-303. http://dx.doi.org/10.1590/S0101-20612001000300008

Campos, F., Carvalho, G., Santos, E., Araújo, G., Gois, G., Rebouças, R., ... Leite, L. (2017). Influence of diets with silage from forage plants adapted to the semi-arid conditions on lamb quality and sensory attributes. Meat science, 124, 61-68. https://doi.org/10.1016/j.meatsci.2016.10.011 
Cooper, S., Sinclair, L., Wilkinson, R., Hallett, K., Enser, M., \& Wood, J. (2004). Manipulation of the n-3 polyunsaturated fatty acid content of muscle and adipose tissue in lambs. Journal Of Animal Science, 82(5), 1461-1470. https://doi.org/10.2527/2004.8251461x

De Nóbile, F. O., \& Nunes, H. D. (2014). Avaliação da produção de etanol e cogeração de energia pela cultura do sorgo sacarino. Revista Brasileira Multidisciplinar, 17(1), 89-98.

Devincenzi, T., Prunier, A., Meteau, K., \& Prache, S. (2019). How does barley supplementation in lambs grazing alfalfa affect meat sensory quality and authentication? , 13(2), 427-434. https://doi.org/10.1017/S1751731118001477

Fernandes, M. A. M., Monteiro, A. L. G., Poli, C. H. E. C., Barros, C. S., Almeida, R., \& Ribeiro, T. M. D. (2010). Tissue composition of carcass and meat fatty acids profile of lambs finished on pasture and feedlot systems. Revista Brasileira de Zootecnia, 1600-1609. http://dx.doi.org/10.1590/S1516-35982010000700029

Franco, D., Crecente, S., Vázquez, J. A., Gómez, M., \& Lorenzo, J. M. (2013). Effect of cross breeding and amount of finishing diet on growth parameters, carcass and meat composition of foals slaughtered at 15 months of age. Meat Science, 93(3), 547-556. https://doi.org/10.1016/j.meatsci.2012.11.018

French, P., O'riordan, E., Monahan, F., Caffrey, P., \& Moloney, A. (2003). Fatty acid composition of intra-muscular triacylglycerols of steers fed autumn grass and concentrates. $\begin{array}{llll}\text { Livestock } \quad \text { Production } & \text { Science, } & \text { 81(2-3), }\end{array}$ https://doi.org/10.1016/S0301-6226(02)00253-1

Hamm, R. (1961). Biochemistry of Meat Hydration Advances in Food Research (Vol. 10, pp. 355-463): Elsevier.

He, L., Wu, H., Wang, G., Meng, Q., \& Zhou, Z. (2018). The effects of including corn silage, corn stalk silage, and corn grain in finishing ration of beef steers on meat quality and oxidative stability. Meat science, 139, 142-148. https://doi.org/10.1016/j.meatsci.2018.01.023

Holanda Júnior, E. (2006). Sistemas de produção de pequenos ruminantes no semi-árido do Nordeste brasileiro. [Infoteca]. Embrapa Caprinos e Ovinos-Documentos

Hopkins, D., Toohey, E., Warner, R., Kerr, M., \& Van De Ven, R. (2010). Measuring the shear force of lamb meat cooked from frozen samples: comparison of two laboratories. Animal Production Science, 50(6), 382-385. https://doi.org/10.1071/AN09162

Kempinski, E. M. B. C., Vital, A. C. P., Monteschio, J. O., Alexandre, S., Nascimento, K. F., Madrona, G. S., ... Prado, I. N. (2017). Development and quality evaluation of infant food with oregano essential oil for children diagnosed with cerebral palsy. LWT-Food Science and Technology, 84, 579-585. https://doi.org/10.1016/j.lwt.2017.06.016

Khliji, S., Van De Ven, R., Lamb, T. A., Lanza, M., \& Hopkins, D. L. (2010). Relationship between consumer ranking of lamb colour and objective measures of colour. Meat Science, 85(2), 224-229. https://doi.org/10.1016/j.meatsci.2010.01.002 
Lara, E. C., Bragiato, U. C., Rabelo, C. H., Messana, J. D., \& Reis, R. A. (2018). Inoculation of corn silage with Lactobacillus plantarum and Bacillus subtilis associated with amylolytic enzyme supply at feeding. . Animal Feed Science and Technology, 243, 22-34. https://doi.org/10.1016/j.anifeedsci.2018.07.004

Leão, A. G., Sobrinho, A. G. S., Moreno, G. M. B., Souza, H. B. A., Perez, H. L., \& Loureiro, C. M. B. (2011). Características nutricionais da carne de cordeiros terminados com dietas contendo cana-de-açúcar ou silagem de milho e dois níveis de concentrado. Revista Brasileira de Zootecnia, 1072-1079. http://dx.doi.org/10.1590/S1516-35982011000500019

Madruga, M. S. (1997). Revisão: formação do aroma cárneo. Boletim da Sociedade Brasileira de Ciência e Tecnologia de Alimentos, 31(1), 33-41.

Madruga, M. S., Narain, N., Arruda, S. G. B., Souza, J. G., Costa, R. G., \& Beserra, F. J. (2002). Castration and Slaughter Age Effects on Physical-Chemical, Sensorial and Aromatic Quality of Goat Meat. Revista Brasileira de Zootecnia, 31(3), 1562-1570. http://dx.doi.org/10.1590/S1516-35982002000600028

Madruga, M. S., Sousa, W. H., Rosales, M. D., Cunha, M. G. G., \& Ramos, J. L. F. (2005). Quality of Santa Ines Lamb Meat Terminated with Different Diets. Revista Brasileira de Zootecnia, 34(1), 309-315. http://dx.doi.org/10.1590/S1516-35982005000100035

Manarelli, D. M., Orrico Junior, M. A. P., Retore, M., Vargas Junior, F. M., Silva, M. S. J., Orrico, A. C. A., . . . Neves, F. O. (2019). Productive performance and carcass aspects of lambs fed saccharine sorghum silage. Pesquisa Agropecuária Brasileira. http://dx.doi.org/10.1590/s1678-3921.pab2019.v54.00577

Milewski, S., Purwin, C., Pysera, B., Lipiński, K., Antoszkiewicz, Z., Sobiech, P., . . Illek, J. (2014). Effect of feeding silages from different plant raw materials on the profile of fatty acids, cholesterol, and vitamins A and E in lamb meat. Acta Veterinaria Brno, 83(4), 371-378. https://doi.org/10.2754/avb201483040371

Monteiro, A., Fernandes, M., \& Barros, C. (2007). As pastagens e a qualidade da carne ovina para o consumo humano.

Monteschio, J. O., Burin, P. C., Leonardo, A. P., Fausto, D. A., Silva, A. L. A., Almeida Ricardo, H., ... Vargas Junior, F. M. (2018). Different physiological stages and breeding systems related to the variability of meat quality of indigenous Pantaneiro sheep. PloS one, 13(2), e0191668. https://doi.org/10.1371/journal.pone.0191668

Mottram, D. S. (1998). Flavour formation in meat and meat products: a review. Food Chemistry, 62(4), 415-424. https://doi.org/10.1016/S0308-8146(98)00076-4

Moura, L., Oliveira, E., Fernandes, A., Gabriel, A., Silva, L., Takiya, C., ... Gandra, J. (2017). Feed efficiency and carcass traits of feedlot lambs supplemented either monensin or increasing doses of copaiba (Copaifera spp.) essential oil. Animal Feed Science and Technology, 232, 110-118. https://doi.org/10.1016/j.anifeedsci.2017.08.006 
Neumann, M., Restle, J., Alves Filho, D., Brondani, I. L., Pellegrini, L., \& Freitas, A. (2002). Nutritional Evaluation of the Plant and Silage of Different Sorghum Hybrids (Sorghum bicolor,L. Moench). Revista Brasileira de Zootecnia, 31(1), 293-301. http://dx.doi.org/10.1590/S1516-35982002000200002.

Novello, D., Franceschini, P., \& Quintiliano, D. A. (2008). A importância dos ácidos graxos

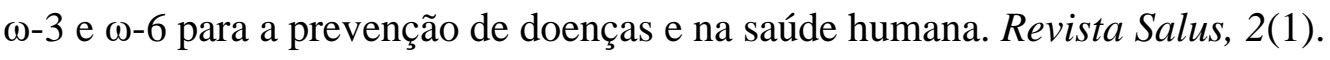

NRC, N. R. C. (2007). Nutrient requirements of small ruminants: sheep, goats, cervids, and new world camelids. (0309102138). The National Academies Press, Washington, DC.

Orrico Junior, M. A. P., Retore, M., Manarelli, D. M., Souza, F. B., Ledesma, L. L. M., \& Orrico, A. C. A. (2015). Forage potential and silage quality of four varieties of saccharine sorghum. Pesquisa Agropecuária Brasileira, 50(12), 1201-1207. http://dx.doi.org/10.1590/S0100-204X2015001200010.

Page, J., Wulf, D., \& Schwotzer, T. (2001). A survey of beef muscle color and pH. Journal of Animal Science, 79(3), 678-687. https://doi.org/10.2527/2001.793678x

Parrella, R. A. C. (2011). Melhoramento genético do sorgo sacarino. Embrapa Milho e Sorgo., 2, Agroenergia em Revista, Brasília, n. 3, p. 8-9, ago. 2011.

Pereira, L., Pires, A. J., Carvalho, G. G., Silva, R. V., Simionato, J. I., Lacerda, E. C., ... Carvalho, B. M. (2016). Nutritional characteristics of lambs meat fed diets with cotton cake. Journal of Food Quality, 39(2), 140-149. https://doi.org/10.1111/jfq.12184

Perini, J. Â. D. L., Stevanato, F. B., Sargi, S. C., Visentainer, J. E. L., Dalalio, M. M. D. O., Matshushita, M., ... Visentainer, J. V. (2010). Omega-3 and omega-6 polyunsaturated fatty acids: metabolism in mammals and immune response. Rev. nutr, 1075-1086. http://dx.doi.org/10.1590/S1415-52732010000600013

Saccà, E., Corazzin, M., Bovolenta, S., \& Piasentier, E. (2019). Meat quality traits and the expression of tenderness-related genes in the loins of young goats at different ages. animal, 1-10. https://doi.org/10.1017/S1751731119000405

Scollan, Choi, N.-J., Kurt, E., Fisher, A. V., Enser, M., \& Wood, J. D. (2001). Manipulating the fatty acid composition of muscle and adipose tissue in beef cattle. British Journal of Nutrition, 85(1), 115-124. https://doi.org/10.1079/BJN2000223

Scollan, Hocquette, J. F., Nuernberg, K., Dannenberger, D., Richardson, I., \& Moloney, A. (2006). Innovations in beef production systems that enhance the nutritional and health value of beef lipids and their relationship with meat quality. Meat science, 74(1), 17-33. https://doi.org/10.1016/j.meatsci.2006.05.002

Sinclair, A. (1993). Dietary fat and cardiovascular disease: the significance of recent developments for the food industry. Food Australia-official journal of CAFTA and AIFST. 


\section{Mll Macrothink}

Journal of Agricultural Studies

ISSN 2166-0379

2020, Vol. 8, No. 2

Tatum, J., Smith, G., \& Belk, K. (2000). New approaches for improving tenderness, quality, and consistency of beef. Journal of Animal Science, 77, 1-10. http://jas.fass.org/content/77/E-Suppl/1.43

Thompson, J. M., Gee, A., Hopkins, D. L., Pethick, D. W., Baud, S. R., \& O’Halloran, W. J. (2005). Development of a sensory protocol for testing palatability of sheep meats. Australian Journal of Experimental Agriculture, 45(5), 469-476. https://doi.org/10.1071/EA03174

Tshabalala, P., Strydom, P., Webb, E., \& De Kock, H. (2003). Meat quality of designated South African indigenous goat and sheep breeds. Meat Science, 65(1), 563-570. https://doi.org/10.1016/S0309-1740(02)00249-8

Ulbricht, T., \& Southgate, D. (1991). Coronary heart disease: seven dietary factors. The Lancet, 338(8773), 985-992. https://doi.org/10.1016/0140-6736(91)91846-M

Vaz, F. N., Restle, J., Silva, N. L. Q., Alves Filho, D., Pascoal, L. L., Brondani, I. L., \& Kuss, F. (2005). Concentrate Level, Sorghum Silage Variety and Genetic Group on Carcass and Meat Quality of Confined Steers. Revista Brasileira de Zootecnia, 34(1), 239-248. http://dx.doi.org/10.1590/S1516-35982005000100028

Wood, J., Richardson, R., Nute, G., Fisher, A., Campo, M., Kasapidou, E., ... Enser, M. (2004). Effects of fatty acids on meat quality: a review. Meat science, 66(1), 21-32. https://doi.org/10.1016/S0309-1740(03)00022-6

\section{Copyright Disclaimer}

Copyright for this article is retained by the author(s), with first publication rights granted to the journal.

This is an open-access article distributed under the terms and conditions of the Creative Commons Attribution license (http://creativecommons.org/licenses/by/4.0/). 